\title{
Pertambahan Bobot Badan Larva Ulat Hongkong (Tenebrio Molitor L.) dengan Penambahan Styrofoam Di Dalam Pakan
}

\author{
Iding, Bachtar Bakrie, dan Maria Aditia Wahyuningrum \\ Program Studi Agroteknologi Fakultas Pertanian Universitas Respati Indonesia Jakarta \\ Email: dinar.biond@gmail.com
}

\begin{abstract}
Abstrak
Taman Margasatwa Ragunan salah satu tempat rekreasi di Jakarta yang ramai dikunjungi. Permasalahan sampah yang ditinggalkan oleh pengunjung seperti styrofoam dikarenakan pengelolaan sampah yang belum optimal. Larva ulat Hongkong diketahui dapat mengurai sampah anorganik seperti Styrofoam. Penelitian ini bertujuan untuk mengetahui pertambahan bobot badan larva ulat Hongkong (Tenebrio molitor L.) dengan penambahan styrofoam secara ad libitum di dalam pakan. Larva ulat Hongkong yang digunakan berumur 35 hari setelah menetas sebanyak 2.000 ekor. Penelitian menggunakan Rancangan Acak Lengkap (RAL) dengan dua faktor (pakan dan styrofoam), terdiri atas 4 perlakuan dan 5 ulangan sehingga berjumlah 20 wadah pemeliharaan dengan masing-masing wadah pemeliharaan berisi 100 ekor. Pakan perlakuan terdiri dari 4 level terdiri dari P1 (100\% pakan ayam komersil bentuk pellet) tanpa pemberian styrofoam, P2 (75\% pakan ayam komersil bentuk pellet + styrofoam), P3 (50\% pakan ayam komersil bentuk pellet + styrofoam), P4 (25\% pakan ayam komersil bentuk pellet + styrofoam). Variabel penelitian yaitu pertambahan bobot badan dan konversi pakan. Pengamatan jumlah konsumsi dan sisa pakan dilakukan per 10 hari dari awal penelitian dan 10 hari terakhir dilakukan setiap hari sampai akhir penelitian, pengamatan konsumsi dan sisa styrofoam dilakukan pada 10 hari terakhir, sedangkan pengamatan pertambahan bobot badan larva ulat Hongkong dilakukan per 10 hari dari awal sampai dengan akhir. Hasil penelitian menunjukkan bahwa perlakuan penambahan styrofoam di dalam pakan berpengaruh terhadap pertambahan bobot badan, konsumsi pakan dan konversi pakan. Perlakuan 2 dengan persentase pemberian pakan $75 \%$ dari kebutuhan pokoknya, memberikan hasil terbesar pada pertambahan bobot badan larva ulat Hongkong yaitu 0,82 gram/100 ekor/hari atau 0,0082 gram/ekor/hari dan konsumsi pakan 3,25 gram/100 ekor/hari).
\end{abstract}

Kata kunci : Larva ulat Hongkong, Tenebrio molitor L., Mealworm, Pertambahan Bobot Badan

\begin{abstract}
Ragunan Wildlife Park is one of the most visited recreational areas in Jakarta. The problem of waste left by visitors such as Styrofoam is due to inadequate waste management. Hong Kong caterpillar larvae are known to break down inorganic waste such as Styrofoam. This study aims to determine the weight gain of Hong Kong caterpillar larvae (Tenebrio molitor L.) with the addition of styrofoam ad libitum in the feed. The Hong Kong caterpillar larvae used were 35 days after hatching as many as 2,000. The study used a completely randomized design (CRD) with two factors (feed and styrofoam), consisting of 4 treatments and 5 replications so that there were 20 maintenance containers with 100 each containing 100 birds. The treatment feed consisted of 4 levels consisting of P1 (100\% pelleted commercial chicken feed) without styrofoam, P2 (75\% pellet + styrofoam commercial chicken feed), P3 (50\% pellet commercial chicken feed + styrofoam), P4 ( $25 \%$ commercial chicken feed in the form of pellets + styrofoam). The research variables were body weight gain and feed conversion. Observation of the amount of consumption and leftover feed was carried out every 10 days from the start of http://ejournal.urindo.ac.id/index.php/pertanian
\end{abstract}

Article History :

Sumbitted 19 Desember 2020, Accepted 30 Desember 2020, Published 31 Desember 2020 
the study and the last 10 days were carried out every day until the end of the study, the observation of consumption and residual styrofoam was carried out in the last 10 days, while the observation of body weight gain of Hong Kong caterpillar larvae was carried out every 10 days from beginning to with the end. The results showed that the addition of styrofoam in the feed had an effect on body weight gain, feed consumption and feed conversion. Treatment 2 , with a percentage of $75 \%$ of its basic needs, gave the largest results in weight gain of Hong Kong caterpillar larvae, namely 0.82 grams / 100 birds / day or 0.0082 grams / head / day and feed consumption 3.25 grams / 100 tails / day).

Keywords: Hong Kong caterpillar larvae, Tenebrio molitor L., Mealworm, body weight gain

\section{PENDAHULUAN}

Unit Pengelola Taman Margasatwa Ragunan adalah salah satu lembaga konservasi ex situ dan tempat rekreasi di Jakarta dengan jumlah pengunjung yang selalu meningkat setiap tahunnya dan bisa mencapai angka 5 juta per tahunnya. Kunjungan yang banyak tersebut memiliki dampak positif dan negatif. Salah satu dampak negatif adalah tumpukan sampah anorganik yang berasal dari pengunjung baik itu yang mereka bawa dari luar maupun dari dalam Taman Margasatwa Ragunan itu sendiri.

Pengelolaan dan pengolahan sampah organik sudah dilakukan baik secara alami maupun dengan menggunakan mesin pengolahan sampah. Pengelolaan dan pengolahan sampah anorganik belum dilakukan penanganan khusus yang serius, pengelolaan dan pengolahan sampah plastik seperti styrofoam belum optimal, baru sebatas daur ulang. Banyaknya pengunjung yang masih mengabaikan larangan penggunaan styrofoam dan kurang optimalnya pengolahan sampah menyebabkan peningkatan penumpukan sampah styrofoam di UP. Taman Margasatwa Ragunan.

Permasalahan limbah khususnya styrofoam yang masih tinggi ini menarik peneliti untuk mencari solusi penanganan sampah anorganik tersebut. Oleh karena itu peneliti ingin menguji pemanfaatan jenis insekta atau serangga yang tergolong ke dalam ordo Coleoptera yaitu larva ulat Hongkong (Tenebrio molitor L.) sebagai pengurai sampah anorganik. Kondisi di lapangan menggambarkan bahwa sampah anorganik hanya dibuang dan ditumpuk pada lubang besar di areal sebelah selatan dari UP. TMR, kemudian akan ditutup kembali dengan tanah yang ada di sekitarnya apabila sudah penuh, selanjutnya akan membuat galian lubang yang baru di lokasi yang berbeda sebagai tempat pembuangan sampah anorganik yang baru. Hal ini terus dilakukan dan akan berdampak negatif terhadap lingkungan di masa yang akan datang. Harapannya UP. 
Taman Margasatwa Ragunan dapat mengaplikasikan hasil penelitian ini untuk mengatasi masalah pengelolaan dan pengolahan sampah anorganik.

Larva ulat Hongkong (Tenebrio molitor L.) merupakan salah satu sumber protein hewani, disukai dan diberikan kepada satwa aves, reptil, beberapa satwa mamalia kecil ataupun primata sebagai pakan tambahan. Pemberian larva ulat Hongkong pada satwa dilakukan seminggu 2 kali untuk memenuhi kebutuhan protein dalam tubuh satwa yang mengkonsumsinya, sementara pakan yang rutin adalah pakan pokok dari masingmasing satwa yang sudah dianalisa secara akademik baik nutrisi dan jumlah kebutuhan optimumnya. Larva ulat Hongkong saat ini sudah banyak dibudidayakan dan dapat dengan mudah dijumpai pada toko-toko pakan burung berkicau, toko penjual ikan hias, komunitas penyayang reptil dan ternak lainnya serta sering dijadikan suplemen atau makanan utama pada hewan-hewan peliharaan dalam bentuk masih hidup maupun berbentuk pellet. Larva ulat Hongkong dijadikan sebagai pakan favorit karena memiliki kandungan nutrisi yang baik untuk hewan ternak. Kandungan nutrisi dalam larva ulat Hongkong meliputi protein kasar $37,80 \%$, lemak kasar 28,63\%, kadar abu $13,36 \%$, serat kasar $7,28 \%$ dan bahan kering $84,31 \%$. Pakan yang digunakan umumnya masih menggunakan polar dan jenis konsentrat lain yang murah [1].

Larva ulat Hongkong yang diberikan kepada satwa tersebut berumur kisaran 50 - 60 hari setelah menetas dalam jumlah yang sedikit karena hanya bersifat feed additive. Larva ulat Hongkong belum dikenal secara meluas dikalangan masyarakat, umumnya hanya terkenal dikalangan pecinta burung berkicau, ikan hias dan reptil. Keistimewaannya selain memiliki nilai ekonomis sebagai pakan burung berkicau, ikan hias, jenis reptil dan beberapa jenis primata, juga mengandung protein tinggi, mudah dipelihara oleh kalangan ibu rumah tangga, tidak membutuhkan tempat yang luas dan biaya yang mahal, dapat diolah sebagai panganan olahan serta dapat digunakan sebagai pengurai sampah plastik seperti styrofoam.

\section{METODE}

\section{Bahan dan Alat}

Bahan yang digunakan adalah larva ulat Hongkong berumur 35 hari setelah menetas, pakan ayam komersil berbentuk pellet, styrofoam wadah kemasan makanan. Peralatan yang digunakan selama penelitian adalah kotak Thinwall berbahan plastik berukuran panjang 17,5 $\mathrm{cm}$, lebar $12 \mathrm{~cm}$ dan tinggi $7 \mathrm{~cm}$ 
berkapasitas $1000 \mathrm{ml}$ sebanyak 20 set, timbangan digital, kertas label, dan alat pengukur suhu portable yang memuat ukuran suhu dan kelembaban.

\section{Rancangan Penelitian}

Penelitian ini menggunakan Rancangan Acak Lengkap terdiri dari 4 perlakuan dan 5 ulangan. Adapun perlakuan yang digunakan adalah sebagai berikut : Perlakuan $1(\mathrm{P} 1)=100 \%$ pakan ayam komersial bentuk pellet, Perlakuan 2 $(P 2)=75 \%$ pakan ayam komersial bentuk pellet + Styrofoam (ad libitum), Perlakuan $3(\mathrm{P} 3)=50 \%$ pakan ayam komersial bentuk pellet + Styrofoam (ad libitum), dan Perlakuan $4(\mathrm{P} 4)=25 \%$ pakan ayam komersial bentuk pellet + Styrofoam (ad libitum).

\section{Cara Kerja}

\section{Persiapan Larva Fase Kepik - Telur menetas umur 15 hari}

Fase ini dilakukan dengan pertimbangan bahwa selain saat itu tidak tersedia larva dengan umur yang diinginkan yaitu 15 hari. Selanjutnya kepik tersebut dipisahkan di nampan besar masing-masing 200 ekor yang di dalam nampan tersebut diberikan media bertelur berupa bekas tray telur. Setiap hari kepik tersebut diberikan pakan ayam komersial bentuk pellet. Setelah 10 hari pemeliharaan dan telur tersebut menetas, larva dipisahkan dari induk kepik ke dalam wadah pemeliharaan yang akan digunakan sebagai kandang pemeliharaan selama penelitian. Pemisahan tersebut dilakukan dengan menempatkan larva ke dalam wadah pemeliharaan sebanyak masingmasing wadah 100 ekor larva agar dapat beradaptasi dengan wadah pemeliharaan. Setiap hari dilakukan pengecekan dan pemberian pakan ayam komersil bentuk pellet sampai larva tersebut memasuki umur 25 hari.

\section{Persiapan Larva Fase Pra Penelitian umur} 25 hari - 34 hari

Setelah umur 25 hari, larva dipelihara di Laboratorium Kesehatan Satwa UP. Taman Margasatwa Ragunan. Pengacakan penempatan wadah pemeliharaan secara acak. Tiap wadah pemeliharaan diberikan label dengan notasi $P$ (Perlakuan) dan $U$ (Ulangan) meliputi P1 (Perlakuan 1) dengan Ulangan 5 kali sehingga menghasilkan notasi P1U1, P1U2, P1U3, P1U4 dan P1U5, hal ini berlaku juga untuk pemberian notasi pada perlakuan 2,3 dan 4 dengan ulangan yang sama sebanyak 5 kali. Total wadah pemeliharaan ada 20 wadah dengan masing - masing wadah berisi 100 ekor larva. Setelah dilakukan pengacakan sesuai prinsip metode RAL, maka dihasilkan susunan penempatan seperti terlihat pada Gambar 1. Bagan Rancangan Acak Lengkap. 
Selama fase ini, pemberian pakan dilakukan tiap hari mengganti ganti pakan baru dengan takaran menyesuaikan ukuran larva ulat Hongkong dengan pemberian styrofoam dalam jumlah sedikit (ad libitum) tanpa ditimbang pada perlakuan 2 , perlakuan 3 dan perlakuan 4 dengan masing-masing ulangannya 5 kali. Hal ini dilakukan secara terus menerus sampai memasuki umur larva ulat Hongkong 34 hari setelah menetas.

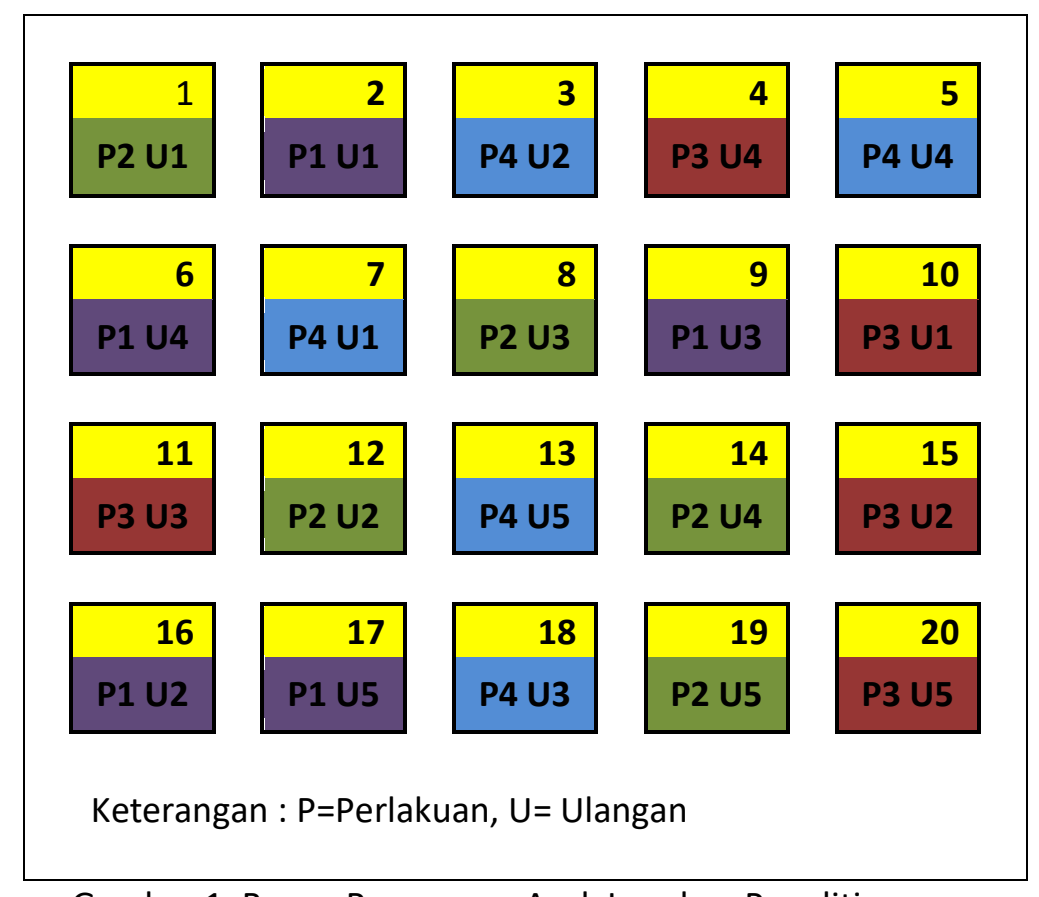

Gambar 1. Bagan Rancangan Acak Lengkap Penelitian

\section{Pemeliharaan Larva Fase Penelitian umur}

\section{5 hari - 75 hari}

Fase ini merupakan fase penelitian yaitu pemberian pakan ayam komersil untuk setiap perlakuan dan ulangan. Setiap hari disiapkan takaran pakan ayam komersil bentuk pellet (ditumbuk setengah halus) sesuai perlakuan dalam plastik klip ukuran $10 \mathrm{~cm} \times 6 \mathrm{~cm}$, menimbang sisa pakan dan dilakukan pencatatan berat sisa pakan sekaligus dikonversikan ke konsumsi pakan untuk per 100 ekor tiap wadah pemeliharaan. Hal ini dilakukan untuk mengetahui kebutuhan konsumsi pakan yang ideal. Pada styrofoam tidak dilakukan penimbangan dan penggantian setiap hari selama fase ini.

Penimbangan bobot badan tiap wadah pemeliharaan dilakukan pada awal penelitian atau hari ke 1 (umur larva 35 hari ), dilanjutkan setiap 10 hari sekali yaitu dihari ke 11 (umur larva 46 hari), hari ke 21 (umur larva 56 hari), hari ke 31 (umur larva 66 hari), hari ke 41 (umur larva 76 hari) dan hari ke 51 (umur larva 86 hari). Selain itu, pakan ayam komersil bentuk pellet yang 
akan diberikan selama pra penelitian sampai selesai penelitian ditimbang sebanyak 300 gram untuk pemeriksaan laboratorium yang meliputi pemeriksaan energi, pemeriksaan kadar air dan pemeriksaan protein.

\section{Pengambilan data (Larva umur 76 hari sampai 85 hari)}

Fase ini merupakan fase utama penelitian yaitu seluruh data sisa pakan ayam komersil, konsumsi pakan tiap populasi larva dalam tiap wadah penelitian sesuai perlakuan dan ulangan, sedangkan untuk pertambahan bobot populasi larva tiap wadah pemeliharaan sesuai perlakuan dan ulangan dicatat per 10 hari dan dijadikan data utama penelitian untuk kepentingan analisa data selanjutnya.

Pencatatan berat pemberian styrofoam dan sisa styrofoam dilakukan pada 10 hari terakhir atau dimulai sejak hari ke 41 (umur 76 hari) sampai hari ke 51 (umur 86 hari). Adapun berat pemberian styrofoam untuk masing-masing wadah pemeliharaan pada perlakuan 2 , perlakuan 3 dan perlakuan 4 dengan masing-masing diulang 5 kali yaitu seberat 0,5 gram atau 500 mg (untuk mengukur konsumsi dan sisa styrofoam). Styrofoam diganti setiap hari dan ditimbang sisa styrofoam untuk menentukan jumlah konsumsi styrofoam dari masing-masing perlakuan dan ulangan.

\section{Variabel Pengamatan}

\section{Konsumsi ransum}

Konsumsi pakan (g) merupakan selisih dari jumlah pakan yang diberikan selama 1 minggu dengan jumlah sisa pakan [2]. Rumus konsumsi pakan (g/ekor) sebagai berikut :

= pakan pemberian $(\mathrm{g})-$ pakan sisa $(\mathrm{g})$

Konsumsi pakan dihitung berdasarkan konsumsi Bahan Kering (BK) per larva per hari yang diukur 2 periode yaitu umur 35-75 dan 76-86 yaitu berdasarkan perlakuan pakan yang diberikan. Perhitungan dan pengukuran konversi pakan dilakukan untuk semua perlakuan dan ulangannya hari ke 41 (umur larva 76 hari) sebagai hari ukur pertama dan hari ukur kedua untuk semua perlakuan dan ulangannya hari ke 42 (umur larva 77 hari) sampai hari ke 51 (umur larva 86 hari) meliputi Jumlah Pemberian Pakan (JPP), Jumlah Sisa Pakan (JSP), Jumlah Konsumsi Pakan (JKP) dan Total Jumlah Konsumsi Pakan Ayam Komersil (TJKP) selama 50 hari.

\section{Konversi Pakan}

Nilai tingkat konversi pakan adalah dengan membagi Jumlah Konsumsi Pakan (JKP) masing-masing perlakuan dan ulangannya dengan Total Pertambahan Bobot Badan (TPBB) larva ulat Hongkong tiap perlakuan dan ulangannya, sedangkan tingkat konversi pakan campuran dengan 
membagi Jumlah Konsumsi Pakan

Pertambahan Bobot Badan Harian (PBBH)

Campuran (JKPC) tiap perlakuan dan Larva Ulat Hongkong (Tenebrio molitor L.) ulangannya dengan Total Pertambahan Pertambahan bobot badan larva dapat Bobot Badan larva ulat Hongkong tiap diketahui dengan penimbangan bobot perlakuan dan ulangannya. hidup.

PBBH (gr/hari) $=$ Bobot badan akhir - bobot badan awal

Lama pemeliharaan (50 hari)

Pertambahan Bobot Badan per 10 hari

Penimbangan bobot badan larva dilakukan pada hari ke 1 , hari ke 11 , hari ke 21 , hari ke 31 , hari ke 41 , hari ke 42 , hari ke 43 , hari ke 44 , hari ke 45 , hari ke 46 , hari ke 47 , hari ke 48, hari ke 49, hari ke 50 dan hari ke 51. Perhitungan rata-rata pertambahan bobot badan dilakukan per 10 hari.

\section{HASIL DAN PEMBAHASAN}

Konsumsi Ransum

Pemberian styrofoam secara intensif dicatat dan ditimbang mulai dari hari ke 41 (umur larva 76 hari) sampai hari ke 51 (umur larva 86 hari). Jumlah konsumsi styrofoam dan sisa styrofoam pada perlakuan 2 (P2), perlakuan 3 (P3) dan perlakuan 4 (P4) pada hari ke 41 dan pada hari ke 42 - hari ke 51 dapat dilihat pada Tabel 1:

Tabel 1. Jumlah konsumsi dan sisa styrofoam hari ke 41 dan hari ke 42 sampai dengan hari ke 50 (gram)

\begin{tabular}{llcccc}
\hline \multirow{2}{*}{ No } & Perlakuan & \multicolumn{2}{c}{ Jumlah Konsumsi } & \multicolumn{2}{c}{ Sisa Styrofoam } \\
\cline { 3 - 6 } & & Hari ke 41 & Hari ke 42-50 & Hari ke 41 & Hari ke 42-50 \\
\hline 1 & P2 & 0,12 & 0,14 & 0,38 & 0,36 \\
2 & P3 & 0,15 & 0,16 & 0,35 & 0,34 \\
3 & P4 & 0,35 & 0,36 & 0,15 & 0,14 \\
\hline
\end{tabular}

Perbedaan kualitas media pakan berpengaruh terhadap jumlah konsumsi pakan larva. Secara langsung bahwa perbedaan kualitas pakan akan menyebabkan perbedaan pertumbuhan dari larva ulat Hongkong (Tenebrio molitor L.) [1]. Hal ini sesuai juga dengan pendapat yang menyatakan bahwa kualitas pakan akan memberikan pengaruh terhadap pemberian gizi bagi larva untuk berkembang [3].

Kemampuan larva ulat Hongkong (Tenebrio molitor L.) mengkonsumsi styrofoam akan meningkat dengan bertambahnya tingkatan instar, oleh sebab itu instar akhir lebih banyak mengkonsumsi 
styrofoam dibandingkan instar awal. Hal ini disebabkan karena instar akhir akan memasuki fase pupa yang membutuhkan pakan lebih banyak dibandingkan instar awal [4]. Hasil pencatatan jumlah konsumsi styrofoam selama penelitian pada 10 hari terakhir menunjukkan rata-rata kenaikan tingkat konsumsi styrofoam. Pada hari ke 41 menunjukkan hasil rata-rata konsumsi styrofoam sebanyak 1,2 gram/100 ekor atau 0,012 gram/ekor untuk perlakuan 2 dan 3 dan 3,4 gram/100 ekor atau 0,034 gram/ekor, sedangkan pada hari terakhir yaitu hari ke 51 menunjukkan hasil ratarata konsumsi styrofoam 1,5 gram/100 ekor atau 0,015 gram/ekor pada perlakuan 2 dan 3 serta 3,6 gram/100 ekor atau 0,036 gram/ekor.

\section{Pertambahan Bobot Badan Larva ulat Hongkong (Tenebrio molitor L.)}

Berikut ini adalah hasil pehitungan perkembangan pertambahan bobot badan larva ulat Hongkong (Tenebrio molitor L.) yang dapat dilihat pada Gambar 2. Total pertambahan bobot badan larva ulat Hongkong diperoleh dari pengurangan antara bobot badan larva ulat Hongkong akhir dengan bobot badan larva ulat Hongkong awal.

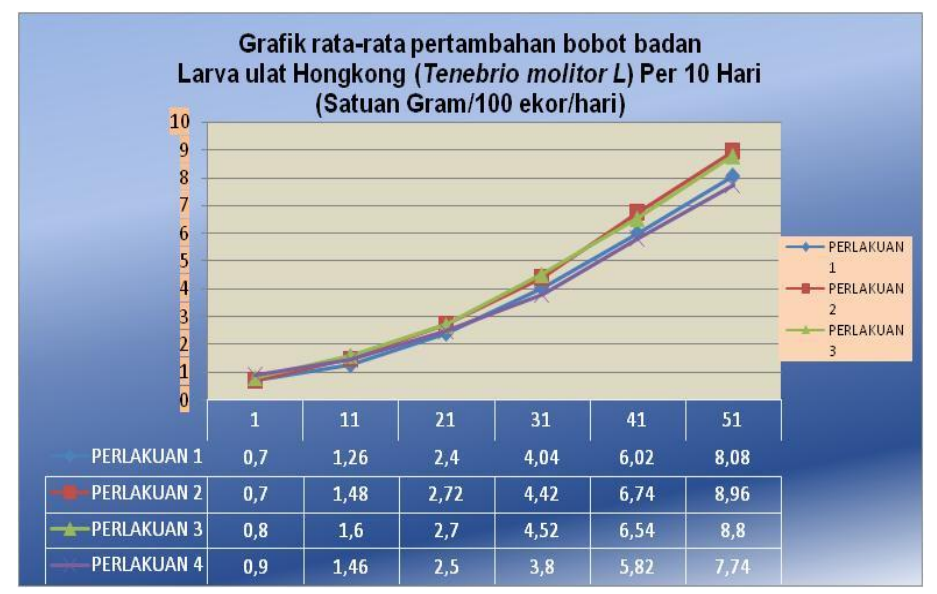

Gambar 2. Pertambahan Bobot Badan Larva ulat Hongkong (Tenebrio molitor L.) Per 10 Hari

Pada Gambar 2 terlihat bahwa kenaikan pertambahan bobot badan larva ulat Hongkong setiap 10 hari sekitar antara 0,5 - 0,8 gram/100 ekor/hari pada 10 hari pertama (hari ke 1-hari ke 11), 1,1-1,3 gram/100 ekor/hari pada 10 hari kedua (hari ke 11-hari ke 21), 1,3 - 1,7 gram/100 ekor/hari pada 10 hari ketiga (hari ke 21- hari ke 31), 1,8 - 2,2 gram/100 ekor/hari pada 10 hari keempat (hari ke 31-hari ke 41) dan 1,9-2,6 gram/100 ekor/hari. Ratarata kenaikan pertambahan bobot larva ulat Hongkong per 10 hari adalah 0,3-0,5 gram/100 ekor/hari. Semakin bertambah bobot badan berbanding sama dengan bertambahnya konsumsi pakan. Selain itu, 
setiap 7-8 hari masing-masing larva akan mengalami proses molting sehingga akan meningkatkan konsumsi terhadap pakan.

Pada Gambar 2 dan Tabel 2 terlihat kenaikan signifikan terjadi pada hari ke 21 yaitu pada perlakuan 2 dan perlakuan 3 . Kenaikan bobot badan perlakuan 2 dan perlakuan 3 terus meningkat pada 10 hari berikutnya sampai akhirnya mencapai bobot optimal pada akhir penelitian yaitu sebesar 8,96 gram/100 ekor/hari pada perlakuan 2 dan sebesar 8,8 gram/100 ekor/hari. Perlakuan 1 dan perlakuan 4 kenaikan bobot badan mulai hari ke 21 tidak signifikan dan hanya mencapai bobot badan maksimal di hari terakhir adalah sebesar 8,08 gram/100 ekor/hari pada perlakuan 1 dan sebesar 7,74 gram/100 ekor/hari. Hal ini menunjukkan bahwa penambahan styrofoam pada perlakuan 2 dengan jumlah pemberian pakan ayam sebesar $75 \%$ (3,9 gram/100 ekor/hari) mampu meningkatkan bobot badan larva ulat Hongkong (Tenebrio molitor L.). Perlakuan 1 dengan jumlah pemberian pakan ayam $100 \% \quad(5,3$ gram $/ 100$ ekor/hari) dan tanpa penambahan styrofoam hanya dapat bertambah bobot badannya tidak jauh selisihnya dengan bobot badan yang dicapai pada perlakuan 4 dengan jumlah pemberian pakan ayam $25 \%$ (1,3 gram/100 ekor/hari) ditambah dengan styrofoam.

Rata-rata pertambahan berat dan pertambahan panjang larva ulat Hongkong semakin bertambah sejalan dengan peningkatan tahapan instar dan peningkatan jumlah pakan yang dikonsumsi [4] . Perkembangan pertambahan bobot badan pada penelitian ini ditimbang per 10 hari yaitu hari ke 1 (umur larva 35 hari), hari ke 11 (umur larva 46 hari), hari ke 21 (umur larva 56 hari), hari ke 31 (umur larva 66 hari), hari ke 41 (umur larva 76 hari) dan hari ke 51 (umur larva 86 hari). Selain pencatatan hasil penimbangan pertambahan bobot badan larva, juga dapat dilihat selisih bobot badan larva ulat Hongkong (Tenebrio molitor L.) selama 50 hari penelitian serta perhitungan Total Pertambahan Bobot Badan (TPBB) yang diperoleh dari hasil pengurangan Bobot Badan Akhir dengan Bobot Badan Awal dibagi 50 hari penelitian.

Tabel 2. Hasil akhir pertambahan bobot badan larva Tenebrio molitor L. dan tingkat konversi pakan dari tiap perlakuan (dalam satuan gram/100 Ekor/50 Hari)

\begin{tabular}{lcccc}
\hline \multirow{2}{*}{ Variabel } & \multicolumn{5}{c}{ Perlakuan } \\
\cline { 2 - 5 } & P1 & P2 & P3 & P4 \\
\hline Bobot Badan Awal & 0,7 & 0,7 & 0,8 & 0,9 \\
Bobot Badan Akhir & 8,08 & 8,92 & 8,84 & 6,24
\end{tabular}




\begin{tabular}{lcccc} 
Pertambahan Bobot Badan & 7,38 & 8,22 & 8,04 & 5,34 \\
Jumlah Konsumsi Pakan & 1,51 & 0,88 & 0,67 & 1,3 \\
Jumlah Konsumsi Styrofoam & 0 & 0,15 & 0,17 & 0,39 \\
Tingkat Konversi Pakan & 0,2 & 0,11 & 0,08 & 0,24 \\
Tingkat Konversi Styrofoam & 0 & 0,02 & 0,02 & 0,07 \\
\hline
\end{tabular}

Penelitian lain menghasilkan PBB larva berkisar 0,20-0,37 gram/ekor pada umur 50 hari yang diberi limbah sayur dan buah [5]. Hasil pertambahan bobot badan yang menggunakan media berbagai jenis kotoran ternak menghasilkan bobot berkisar 1,4-1,6 gram/ekor dan tertinggi 1,6 gram/ekor [6]. Pada penelitian yang dilakukan dengan menggunakan pakan ayam komersil yang ditambahkan styrofoam di dalam pakan pada umur 65 hari menghasilkan rata-rata bobot berkisar 0,038 - 0,045 gram/ekor.

\section{SIMPULAN}

Pertambahan bobot badan larva ulat Hongkong mengalami kenaikan seiring dengan pertumbuhannya. Penambahan styrofoam di dalam pakan pada perlakuan $75 \%$ pakan ayam komersil yang ditambahkan styrofoam menunjukkan hasil yang terbaik dalam meningkatkan pertambahan bobot badan larva ulat Hongkong dibandingkan pada perlakuan pakan $100 \%$ tanpa penambahan styrofoam di dalam pakannya. Kombinasi antara pakan ayam komersil dan styrofoam yang terbaik dan optimal dalam meningkatkan pertambahan bobot badan larva ulat
Hongkong (Tenebrio molitor L.) selama penelitian ini adalah pada perlakuan $75 \%$ pakan ayam komersil (5,3 gram/100 ekor) ditambah dengan styrofoam sebagai ad libitum.

\section{DAFTAR PUSTAKA}

Purnamasari, D, K., Syamsuhaidi., Erwan, \& Wiryawan, K. GH. 2018. Pertumbuhan dan Survival Rate Larva Tenebrio molitor Yang Diberikan Media Pakan Berbeda. Jurnal Peternakan Sriwijaya. 7 (2) :17-23.

Scott, M. L., Nesheim, M., and Young, R. J. 1992. Nutrition of the chicken. Fifth Ed. Scott, M. L. And Associates. Ithaca. New York.

Katayane A.F., Wolayan F.R., Imbar, M.R. 2014. Produksi dan kandungan protein maggot (Hermetia illucens) dengan menggunakan media tumbuh berbeda. J Zootek. 34:27-36.

Deasy, V.C.M. 2018. Kemampuan Berbagai Tingkatan Stadium Larva Kumbang Tenebrio molitor $L$. (Coleoptera:Tenebrionidae) dalam Mengkonsumsi Styrofoam 
(Polystyrene). Jurnal Biologi Eksperimen dan Keanekaragaman Hayati. 5 (1): 83-88.

Hartiningsih dan E. FitaSari. 2014. Peningkatan Bobot Panen Ulat Hongkong Akibat Aplikasi Limbah Sayur Dan Buah Pada Media Pakan Berbeda. Jurnal Buana Sains. 14 (1): 55-64.
Azizi, Z. 2018. Penggunaan Berbagai Jenis Kotoran Ternak Terhadap Pertumbuhan dan Produksi Larva Hermetia illucens. (Kajian Potensi Sebagai Pakan Unggas). Publikasi Ilmiah. Mataram: Program Studi Peternakan, Universitas Mataram. 